\title{
Drill Method: Improving Reading Aloud Skills?
}

\author{
As Janah Verrawati ${ }^{*}$, Wuri Wuryandani, Septia Sugiarsih
}

\author{
Universitas Negeri Yogyakarta \\ "Corresponding author.Email: asjanah.2020@student.uny.ac.id
}

\begin{abstract}
This research was conducted because of students' reading aloud skills and student learning outcomes in Indonesian language content. This study aims to determine the improvement of reading aloud skills using the drill method at class III SD Negeri Petangkuran. This type of research is classroom action research (CAR). The research subjects were third-grade students with 28 students totally in the 2020/2021 school year. The data collection technique uses observation. The data collection instrument was an observation guide sheet. The data analysis technique was carried out in a quantitative descriptive manner. This research was carried out in two cycles by applying the drill method. The learning steps carried out are providing training on how to read with proper pronunciation, intonation, and pauses covering several phases, namely: (1) the phase of giving the exercise, (2) the phase of implementing the exercise, and (3) the phase of being responsible for the exercise. The results showed that the aloud reading skills of the third-grade students improved after using the drill method in learning Indonesian content. This increase is evident in the students' reading skills from a pre-cycle mean score of 61.25 with a minimum completeness percentage of $43 \%$ to 69.8 in the first cycle with a minimum completeness percentage of $67 \%$ and increased to 83.92 in the first cycle. Cycle II is with a minimum completeness percentage of $89 \%$.
\end{abstract}

Keywords: aloud reading skill, drill method, Indonesian Language

\section{INTRODUCTION}

Reading is a complex skill. According to [1], reading aloud is a complex skill. Reading aloud skills are reading skills by voicing written symbols (letters, syllables, words, and sentences) by paying attention to aspects of reading skills (pronunciation, intonation, and punctuation). Reading aloud skills are carried out in elementary school grades I, II, and III.

Reading aloud is an important thing in the world of education. Two reading skills are mechanical reading skills and comprehension reading skills [2]. Reading aloud is a mechanical reading skill at a lower level than reading comprehension. Reading aloud demands a variety of skills. The skills in question are pronunciation and intonation [3]. Pronunciation is a way for a person or group of people to pronounce the sound of a language. Indonesian sounds include Vowels, Consonants, Diphtones, Consonant consonants. In language guidance, there are a number of vonems that are pronounced not in accordance with the correct pronunciation, so the pronunciation is not standard [4]. Intonation is the rise and fall of a sentence. Intonation serves to form the meaning of the sentence examples go (give news), go (expel).
The reading process can be grouped into several types. According to [3], whether or not the reader's voice is heard when reading can be divided into the following: reading aloud and reading silently. Reading aloud is also called reading aloud or reading out loud (reading out loud, oral reading, and reading aloud). Reading silently is also known as silent reading. Reading silently is also known as silent reading. Reading aloud is a reading activity that voices what is read with the aim that listeners can capture information about what is read [5]

Based on several opinions regarding reading aloud, it can be concluded that reading aloud is reading by voicing written symbols (letters, tribes, words, and sentences) by paying attention to aspects of reading skills. The punctuation in question is pronunciation, intonation, pause, and punctuation, which aim to make the reader able to capture information and understand what is contained in a reading text.

The reading skills of third-grade students at SD Negeri Petangkuran are still relatively low. This is indicated by the assessment results of students' aloud reading skills which are still low, namely more than 50 percent of the 28 students who have not been able to read with proper pronunciation, intonation, and punctuation. Based on the results of the third grade 
home teacher interview, they stated that students had not applied the science of reading aloud properly, such as when a comma should be read by pausing for a moment, but some students did not stop for a moment, and some immediately continued the next word after the comma without stopping. In grade 3, students should be fluent in reading so that the teacher can easily deliver the learning materials because the higher the grade level, the more theories, and materials. More and more reading texts must be mastered by students so that learning can run smoothly. There should be special treatment for students to read aloud fluently.

Reading aloud in class III is rarely done in learning, especially during the covid 19 pandemic. Teachers teach reading skills by explaining how to read texts, but the intensity of reading practices is very rare and almost never done during the pandemic. Learning to read aloud should be done before working on questions about a text, but usually, students are only given the task of working on questions related to the content of the text without any aloud reading assignments that the teacher can monitor. The method used by the teacher to teach reading aloud skills is the lecture method which is still monotonous, and the practice of reading aloud is not given much attention. This resulted in 50 percent of the 28 students not reading with proper pronunciation, intonation, and punctuation and still classified as having low aloud reading skills.

Based on the problem of students' low aloud reading skills, a method is needed to increase the class III students' reading aloud activities to improve the aloud reading skills of third grade elementary school students. The method that can train students to improve reading aloud skills is by using the Drill method (practice).

The drill training method is a learning method carried out by training students repeatedly. The drill method is a method used to train dexterity which is done by practicing a skill repeatedly, this is in accordance with the opinion of [6]. The drill training method is a learning method carried out by training students repeatedly. [7] states that the Drill method is a learning method carried out with repeated practice intending to perfect a skill so that it is permanent. [8] also stated that the Drill method is a method that teaches students to carry out training activities so that students have higher skills or dexterity than what has been done before.

Drill method that is done regularly will train students' reading skills. The use of the Drill method is expected to improve students' reading aloud skills. Based on the background of the problem, the authors are interested in researching with the title: improving reading aloud skills using the Drill method in thirdgrade students of SD Negeri Petangkuran for the academic year 2020/2021. Based on the study results, it is hoped that it will be a consideration for teachers in teaching reading aloud skills in the next lesson.
The drill method is a teacher teaching method that aims to train students intensively to have better abilities or skills. Drill method is a way of teaching in which students carry out training activities to have dexterity or skills that are higher than what is learned.

According to [9] in the teaching and learning strategy explains, "Drill method is a good way of teaching to instil certain habits as well as a means to maintain good habits. In addition, it can be used to gain dexterity, accuracy, opportunity, and skill." Drill method, or ready training, is intended to gain dexterity or training skills for what is learned because by only doing practically, a knowledge can be perfected and ready to be prepared [10].

According to [11], special methodical teaching of Islamic religion explains "the use of the term exercise is often equated with the meaning or term of a test, even though the meaning is different, the exercise is intended so that certain knowledge and skills can belong to students and be fully controlled while the test only to measure the extent to which he has absorbed the teaching."

The drill method or exercise is a good way of teaching to instil certain habits and gain dexterity, accuracy, opportunity, and skills for what is learned. In efforts to teach skills using the Drill method or practice, every educator must know the attitude of the skill itself, such as skill as a refinement of meaning and not as a result of a mere mechanical process. These skills are incorrect if they only determine a routine thing that can be achieved by repetition that does not use the mind because the reality of acting or doing must be in accordance with the situation and conditions.

The skill training method is a teaching method in which students are invited to a skill training place to see how to make something, how to use it, what it is made for, what the benefits, etc. The advantages of the skill training method are as follows: students can acquire motor skills, pronounce letters, and use tools. Students can increase their mental and thinking skills, such as critical thinking, creativity, innovation, and problem-solving.

\section{METHOD}

This research is a classroom action research using the research model developed by Stephen Kemmis and Robin Mc Taggart, which uses four research components in each step, namely planning, acting, observing, and reflecting. If visualized, Kemmis and Mc Taggart's model will look like Figure 1.

The research was conducted from February to June 2021. The research site was SD N Petangkuran Kebumen, Indonesia. The research subjects were class III SD N Petangkuran. The number of subjects in this study was 28 students consisting of 16 male students and 12 female students with various student diversity. 


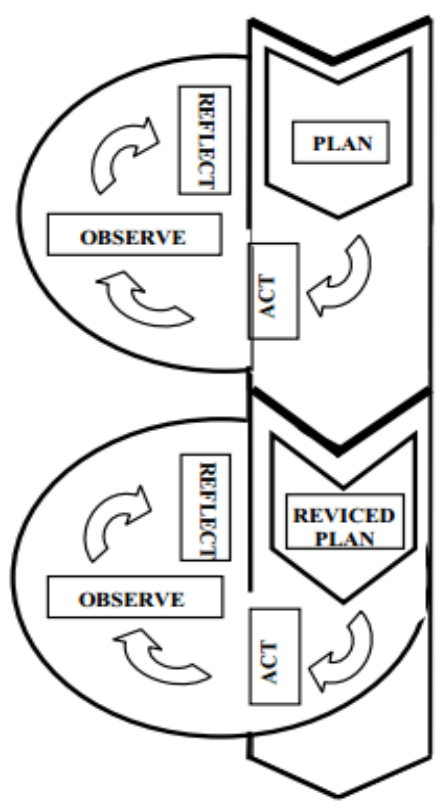

Figure 1 Classroom Action Research Model Kemmis and Mc. Taggart

This research is classroom action research that designed using a spiral model cycle developed by Kemmis and Mc. Taggart, in each cycle, will use four components of action, namely (1) Plan, (2) Act, (3) Observe, and (4) Reflect in an interlocking spiral. The use of the classroom action research model Kemmis and Mc Taggart's model in research is described as follows.

This classroom action research is collaborative action research state that in collaborative research, the party who takes action is the teacher himself, while those who are asked to observe the ongoing process of action are the researcher, not the teacher who is taking action. suggests that group members develop action plans together, act and observe individually and together, and reflect together as well. Then they consciously reformulate the plan based on fuller and more critical information. The technique for collecting data is observation. The instrument used in this research is a guideline for observing the implementation of learning in accordance with the Drill method. The research instrument measured students' reading aloud skills using the Drill method, and the implementation of learning uses the Drill method. According to observation is a complex process that consists of psychological and biological processes. Observation of students' reading skills is also carried out simultaneously with children reading aloud in front of the class or on WhatsApp videos.

\section{RESULTS}

The results of learning observations carried out by classroom teachers are presented in the form of images shown in Figure 2.

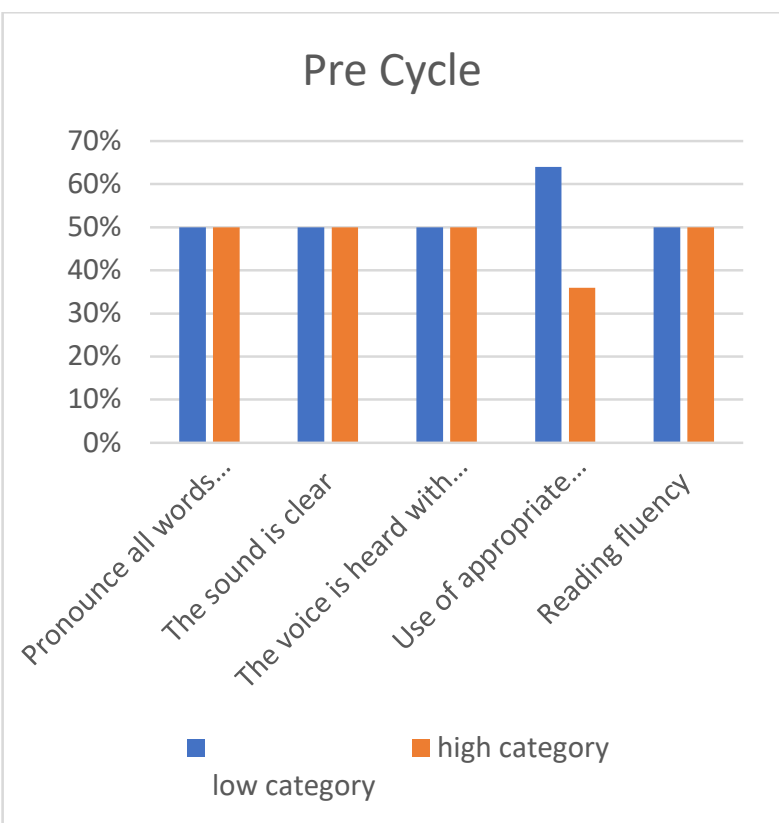

Figure 2 Condition of Students' Reading Aloud Skills Before Cycle

Figure 2 is a graph of the state of the students' reading skills before taking action. There is 50 percent of students who have not pronounced all the words correctly. There is 50 percent of students whose voices still sound unclear when reading aloud. There is 50 percent of students who read with incorrect intonation. There are 64 percent of students who do not use the right rules of punctuation when reading aloud, and 50 percent of students who are less fluent when reading aloud.

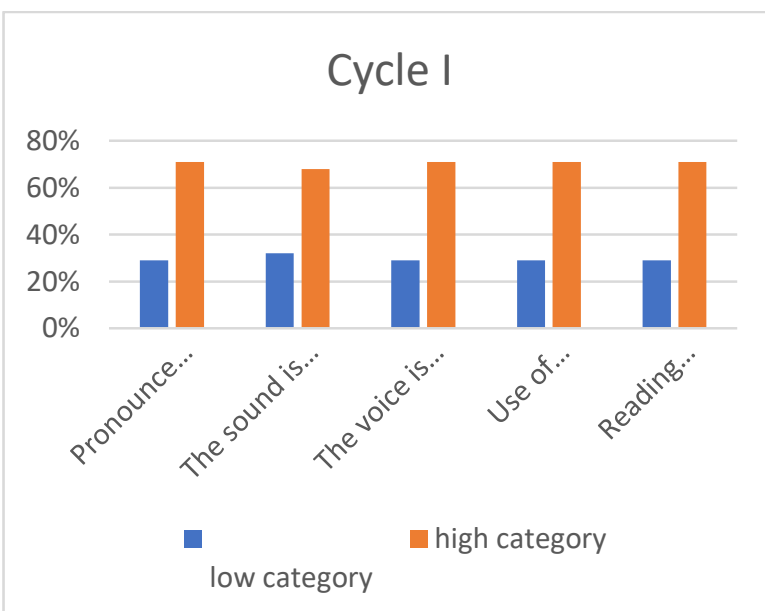

Figure 3 Condition of Students' Reading Aloud Skills in Cycle One

Figure 3 describes the conditions in the first cycle of the study, namely there was an increase in each aspect of students' reading aloud. that is, 71 percent of students are correct in pronouncing all words, then 68 percent of students speak clearly. As many as 71 percent of students' voices are heard with the right intonation. As many as 71 percent of students have 
used pauses that are in accordance with punctuation and are fluent in reading according to the rules of punctuation.

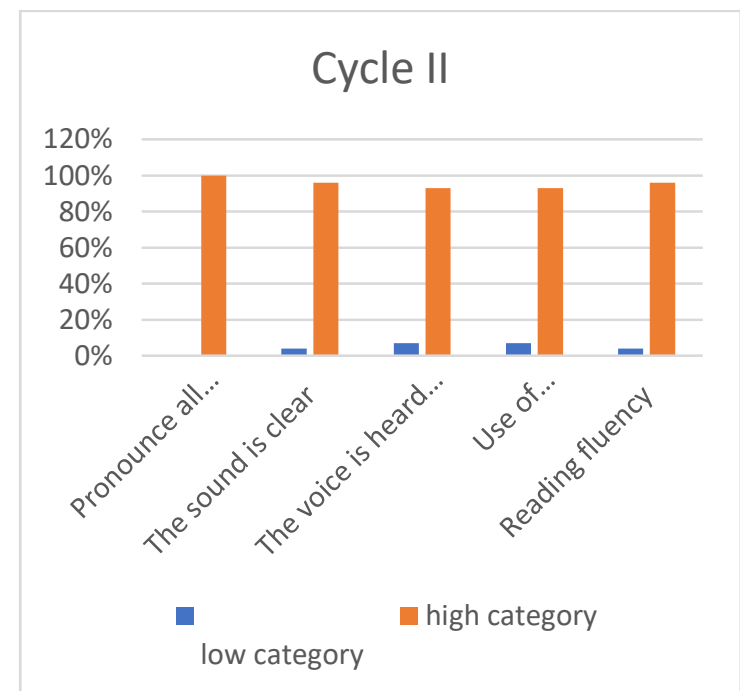

Figure 4 Condition of Students' Reading Aloud Skills in Cycle Two

The picture above describes the conditions in the second cycle of research, namely there is an increase in each aspect of students' reading aloud. 100 percent of students are correct in pronouncing all words, then 96 percent speak clearly. As many as 93 percent of students' voices are heard with the right intonation. As many as 93 percent of students have used pauses that are in accordance with punctuation rules. The percentage of 96 percent of students fluently read according to punctuation rules.

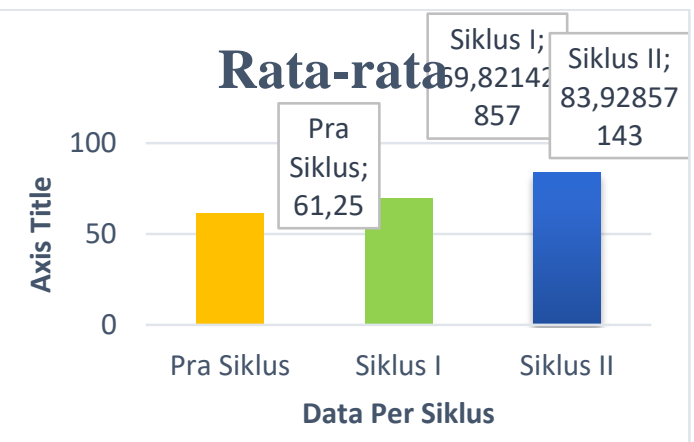

Figure 5 Diagram of the average student scores from pre-cycle, cycle I and cycle II

Based on Figure 5, it can be seen that the average score of students on the assessment of reading aloud skills always increases in each cycle. The increase from pre-cycle to cycle I was 61.25 to 69.8 of 8.57 . The average score increased again in the second cycle, which increased by 13.9 , namely from 69.8 in the first cycle to 83.75 in the second cycle. The average increase from cycle I to cycle II is 14.10 . The increase in the average value of students' reading aloud skills from pre-cycle to the end of cycle II was 22.67 , i.e., 61.25 in pre-cycle to 83.92 in cycle II.

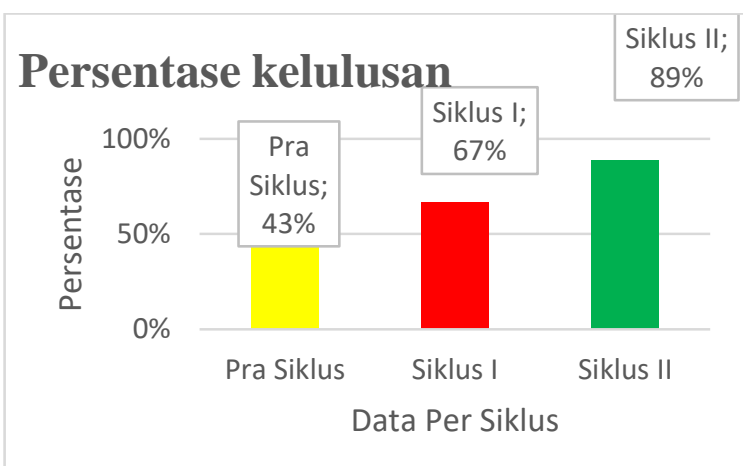

Figure 6 Diagram of the percentage of students passing reading aloud

Based on Figure 6, it can be seen that the percentage of students who pass the KKM aloud reading skills always increases in each cycle. The increase from pre-cycle to cycle I is from $43 \%$ to $67 \%$ by $24 \%$. The percentage of students who passed the KKM aloud reading skills occurred again in the second cycle, which increased by $22 \%$ from $67 \%$ in the first cycle to $89 \%$ in the second cycle.

\section{DISCUSSION}

The research on the aloud reading skills of thirdgrade students at SDN Petangkuran was conducted in 2 cycles. The initial data for students' reading aloud skills comes from the value of reading aloud skills in Indonesian content for grade III SD. The condition of students before the action was taken was 50 percent of students, namely 14 students from a total of 28 students who were not fluent in reading words consisting of 3 to 4 syllables. Punctuation marks, periods, commas, and question marks are still not noticed by students when reading aloud with a percentage of 50 percent of students from a total of 28 students. A total of 14 students read with unclear intonation.

The action results in cycle 1 were eight students out of a total of 28 students still had difficulty pronouncing words with double consonants, for example, tr, br, for example, in words silk and factory. Students pronounce the letter e, for example, "sutra". A total of 9 students voiced the use of vowel words indistinctly was not audible, for example, I was said vaguely. A total of 8 students read with inaccurate intonation in 2 sentences. For example, the tone of the comma should have decreased, but the students only read flatly. A total of 8 students read without paying attention to punctuation pauses (periods and commas). Students did not stop for a moment when there were commas and periods. A total of 8 students are still spelling words consisting of 3 syllables.

The results of the action in cycle II were that all students were able to pronounce words with both consonants, vowels, diphones, and consonant 
combinations with a minimally good category. As many as one student voiced indistinctly, vowel words were not clearly heard. For example, I was said vaguely. A total of 2 students read with inaccurate intonation in 2 sentences. For example, the tone of the comma should have decreased, but the students just read flatly. A total of 2 students read without paying attention to punctuation pauses (periods and commas). Students did not stop for a moment when there were commas and periods. A total of 1 student still spelled a word consisting of 3 syllables.

\section{CONCLUSIONS AND SUGGESTIONS}

The aloud reading skills of third grade students at SDN Petangkuran have increased. This is proven based on the average value of the students' reading aloud skills that increased from the pre-cycle, first cycle, and second cycle of 22.68. The first increase occurred in the pre-cycle to the first cycle, which was up 8.57 from the initial 61.25 in the pre-cycle to 69.8 in the first cycle. The second increase in the average value occurred in the first cycle to the second cycle, which was an increase of 14.10 from the first cycle. initially 69.8 in the first cycle to 83.92 in the second cycle. Based on the average increase, it proves that the use of the drill method can improve the aloud reading skills of the third-grade students.

The percentage of students who passed the KKM aloud reading skills continued to increase from the precycle, first cycle, and second cycle, which was $46 \%$. The first increase in the percentage of students who passed the KKM aloud reading skills occurred in the pre-cycle to the first cycle, which increased by $24 \%$, from initially $43 \%$ in the pre-cycle to $67 \%$ in the first cycle. The second increase in the percentage of students who passed the KKM aloud reading skills occurred in the first cycle to the second cycle by $22 \%$, from $67 \%$ in the first cycle to $89 \%$ in the second cycle. Based on this increase, it is proven that the use of the drill method can improve the aloud reading skills of third grade students. Based on the data above, it can be concluded that the use of the drill method in learning can improve students' reading aloud skills. It is proven by the average value of students and the percentage of students who pass the KKM aloud reading skills which increase in each cycle.
Educators can consider the use of the drill method in improving students' reading aloud skills. Because it has been proven to be able to improve students' reading aloud skills, especially grade III SD Negeri Petangkuran for the 2020/2021 school year.

Educators can use the drill method or training method to improve students' skills and can also conduct further research on students' reading aloud skills or on the use of drill methods to improve skills other than reading aloud.

\section{REFERENCES}

[1] J. Ismail, "Peningkatan Kemampuan Membaca Nyaring Melalui Media Cerita Bergambar pada Siswa Kelas Ii Mishi. Ahmad Syukurdaruba Kabupaten Pulau Morotai," Jurnal Mitra Pendidikan(JMP Online), vol. 3, p. 1536, 2019.

[2] W. N. \&. H. H. Budiarti, "Pengembangan media komik untuk meningkatkan keterampilan membaca pemahaman siswa kelas IV," Prima Edukasia, pp. 233-242, 2016.

[3] G. Tarigan, Membaca Sebagai Suatu Suatu Keterampilan Bernahasa, Bandung: PT. Angkasa, 2008.

[4] L. d. Ali, Pedoman Umum Ejaan Bahasa Indonesia Yang Disempurnakan, Jakarta: Depdikbud, 1996.

[5] G. Purwati, "Peningkatan Keterampilan Membaca Nyaring Melalui Media Cerita," Jurnal Perseda, pp. 179-188, 2019.

[6] S. Ainun, "Peningkatan Kemempuan Siswa Membaca Nyaring," Jurnal Kreatif Tadulako Online, pp. 167-181,, 2020.

[7] N. Sudjana, Dasar-dasar Proses Belajar Mengajar, Bandung: Sinar Baru Angkasa, 1995.

[8] Hamdani, Strategi Belajar Mengajar, bandung: CV. Pustaka Setia, 2009.

[9] S. B. D. d. A. zain, Strategi Belajar Mengajar, Jakarta: PT. Rineka Cipta, 1996.

[10] R. Yulis, Metodologi Pendidikan Agama Islam, Jakarta: Kalam Mulia, 2005.

[11] Z. Drajat, Metode Khusus Pengajaran Agama Islam, Jakarta: Uni Aksara, 1995. 